\title{
Ocular manifestations of HIV/AIDS: A literature review* (Part 1)
}

\author{
P Govendera, R Hansrajb, KS Naidooc and L Visser ${ }^{\mathrm{d}}$
}

a, b, c Discipline of Optometry, School of Physiotherapy, Sport Science and Optometry, Faculty of Health Sciences, University of KwaZulu-Natal, Westville Campus, Private Bag X54001, Durban, 4000 South Africa

d Department of Ophthalmology, Nelson R. Mandela School of Medicine, University of KwaZuluNatal, Umbilo Road, Durban, 4000 South Africa

a, c International Center for Eyecare Education, 172 Umbilo Road, Durban, 4000 South Africa

c African Vision Research Institute, 172 Umbilo Road, Durban, 4000 South Africa

*<govenderp@ukzn.ac.za>

Received 3 June 2010; revised version accepted 19 November 2010

\section{Introduction}

Human Immunodeficiency Virus (HIV), is a retrovirus which causes Acquired Immune Deficiency Syndrome (AIDS)1, 2. Since its discovery in 1981, HIV/AIDS has emerged as a global health problem ${ }^{3}$. The prevalence rate of HIV/AIDS has been reported to be $0.8 \%$ globally, $5 \%$ in Sub-Saharan Africa and $18.8 \%$ in South Africa ${ }^{4,5}$. The impact of the HIV/AIDS pandemic has spurred much research into the disease and its various systemic and ocular complications. Maclean ${ }^{6}$ first described the ocular manifestations of HIV infection more than 20 years ago. The ocular manifestations of HIV/AIDS have been for the most part due to the opportunistic infections and neoplasias that accompany the syndrome ${ }^{7}$. The evolution of HIV and the appearance of new strains of the virus have however, changed the incidence of the disease with resultant changes in AIDS-related eye diseases and blindness. Research has indicated that anti-retroviral therapy has also modified the clinical progression of the disease ${ }^{8}$. The HIV virus has been found in the tear film and other ocular structures such as the cornea, vitreous and chorioretinal tissue ${ }^{9}$. Ocular manifestations have been reported in 70 to $100 \%$ of individuals infected with HIV ${ }^{10},{ }^{11}$. The ocular manifestations may involve the adnexae and anterior and posterior segments of the eye. In addition, HIV/ AIDS also presents with orbital and neuro-ophthalmic manifestations ${ }^{11}$. Anterior segment involvement usually results in tumours and external infections while posterior segment involvement usually results in HIV-retinopathy and a number of opportunistic infections of the retina and the choroid ${ }^{8}$.

Early detection of the ocular manifestations of HIV/ AIDS is critical since these ocular manifestations may be the primary presentation of the systemic infection $^{12}$. This has implications for the prognosis of the disease.

It is difficult to review this topic in one article

\footnotetext{
${ }^{a}$ BOptom (UDW) CAS (NECO) MOptom (UKZN)

b BOptom (UDW) CAS (NECO) MOptom (UDW) PhD (UKZN)

${ }^{\mathrm{c}}$ BSc BOptom (UDW) MPH (Temple) OD (PCO) PhD (UNSW)

d MBChB (Pret) MMED (Ophth) (Natal) FCOphth (SA)
}

*This paper is based on work by P Govender towards a Masters degree in the Discipline of Optometry of the University of KwaZulu-Natal with the supervision of Professor KS Naidoo and Drs R Hansraj and L Visser 
considering the huge body of literature that exists on the ocular manifestations of HIV/AIDS. Therefore, this article is the first (Part 1) of a two part series reviewing this issue. Part one will cover adnexal and anterior segment findings while part two will cover posterior, orbital, neuro-ophthalmic and iatrogenic manifestations of HIV/AIDS.

\section{Adnexal Manifestations of HIV/AIDS}

Adnexal manifestations are restricted to the eyelid, the conjunctiva and the lacrimal drainage system. The most common adnexal manifestations include herpes zoster ophthalmicus (HZO), Kaposi sarcoma, molluscum contagiosum and conjunctival microvasculopathy ${ }^{8}$. Conditions such as blepharitis or blepharoconjunctivitis and keratoconjunctivitis sicca are generally listed as anterior segment manifestations ${ }^{13}$, however, are addressed as adnexal manifestations based on the anatomical classifications used in this article.

\section{Keratoconjunctivitis Sicca (KCS)}

Keratocojunctivitis sicca has been noted as one of the most common ocular anterior segment complications and has been reported in about $20 \%$ of HIV positive individuals 14,15 . The reported symptoms include foreign body sensation, photophobia and decreased visual acuity as a result of $\mathrm{KCS}^{14}$. Anecdotal reports have also suggested that individuals with KCS are more susceptible to bacterial keratitis and abnormalities in the composition of the tear film. Although the exact pathogenesis of these changes is unclear in HIVinfected individuals ${ }^{16}$ researchers have suggested that the condition is attributed to HIV-mediated inflammation, direct damage to the accessory and major lacrimal glands ${ }^{12}$ and in addition, lymphocytic infiltration of the lacrimal gland ${ }^{13}$.

\section{Blepharitis and blepharoconjunctivitis}

Although blepharitis has not been studied in detail in HIV-infected individuals ${ }^{16}$ owing to the scholarly demands of understanding the more severe, blinding disorders, it has been found to be more common and more serious in HIV-infected individuals ${ }^{13}$. The condition could be attributed to a reduced ability to control the normal flora that the eye is exposed to or to more complex changes that occur in the cutaneous glands of the eyelids with immunosuppression ${ }^{17}$. Jeng et a ${ }^{16}$ noted that the symptoms of blepharitis in HIVinfected individuals could be heightened due to the concurrent dry eye. The lid and conjunctival disease associated with recurrent ocular herpes simplex can occur as blepharitis, blepharoconjunctivitis and follicular conjunctivitis ${ }^{18}$.

\section{Herpes Zoster Ophthalmicus (HZO)}

$\mathrm{HZO}$ is a painful vesiculobullous dermatitis which results from a reactivation of Varicella-Zoster virus infection ${ }^{19}$. Literature has suggested that HZO might be the initial clinical manifestation of HIV infection in young individuals ${ }^{20}$, particularly those younger than 50 years of age 21-23. Pavan-Langston ${ }^{24}$ showed that HIV-positive individuals have a 15 to 25 times greater prevalence of HZO than the general population. The most common predisposing factor to developing $\mathrm{HZO}$ is age. However, other factors include neoplasm, HIV infection, trauma, irradiation, immunosuppression, surgery or debilitating systemic disease ${ }^{19,25}$.

Varicella-Zoster Virus (VZV) is a double-stranded DNA virus of the herpes family which causes HZO. VZV causes Varicella (chicken pox) upon initial infection and shingles or zoster on recurrence ${ }^{26}$. Initial infection occurs when the virus comes in contact with the mucosa of the respiratory tract or conjunctiva. The virus is then distributed throughout the body through mononuclear cells in the blood while it spreads from cell to cell through direct contact in the tissues ${ }^{27}$. After the primary infection, the virus migrates along the sensory nerve fibers to the satellite cells of the dorsal root ganglion of the trigeminal nerve where it remains dormant. The dormancy may be permanent or the virus may become reactivated when there is a decrease in cellular immunity, thereby resulting in herpes zoster ${ }^{26}$. Once reactivated, the virus travels from the ganglion along the sensory nerve (that is, the ophthalmic division of the trigeminal nerve) to the skin, eye and adnexae. The ophthalmic division of the trigeminal nerve is involved 20 times more frequently than the maxillary and mandibular divisions of the trigeminal nerve ${ }^{19}$. The initial infection with the virus usually confers lifelong protection against subsequent 
attacks however, in about $20 \%$ of cases, reactivation occurs and is more common in immune-compromised individuals like those who are organ transplant recipients, those who suffer from AIDS, neoplasm or blood dyscrasia ${ }^{25}$. The extreme pain and post-herpetic neuralgia experienced by those infected is thought to result from tissue destruction and neuronal changes in the ganglion ${ }^{26}$.

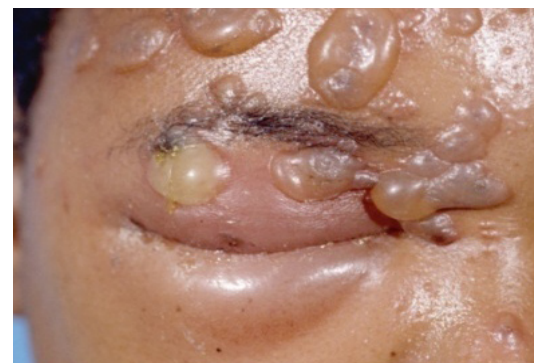

Figure 1. Vesiculobullous dermatitis of Herpes Zoster Ophthalmicus (Photo Courtesy of Dr Linda Visser)

Manifestation of HZO usually begins as pain over the first division of the trigeminal nerve. This pain lasts for several days and is followed by erythematous macules which progress within days into papules and vesicles and later pustules (see Figure 1) which rupture and crust ${ }^{19}$. The skin manifestations respect the vertical midline strictly unlike that of Herpes Simplex virus ${ }^{27}$. When the nasociliary branch is involved, a vesicle may appear on the tip or side of the nose. This is referred to as Hutchinson's sign and has been identified as a clinical predictor of ocular involvement ${ }^{19,28}$. HZO can result in various ocular pathologies including vesicular eruptions on the eyelids, blepharitis which can lead to secondary bacterial infection, eyelid scarring, marginal notching, madarosis, trichiasis and cicatricial entropion. A ptosis secondary to the oedema and inflammation has also been observed ${ }^{19}$.

Corneal involvement is present in approximately $65 \%$ of cases of $\mathrm{HZO}^{24}$. The earliest manifestation of corneal involvement is epithelial keratitis characterised by multiple, focal swollen lesions which stain better with Rose Bengal than fluorescein ${ }^{26}$. These lesions form a branching pattern with tapering ends, contain live virus and may either resolve or progress into dendrites which appear as elevated plaques and consist of swollen epithelial cells ${ }^{19}$. In addition to these classic symptoms and lesions, other common manifestations include conjunctivitis, scleritis, episcleritis, keratitis, iridocyclitis, Argyll-Robertson pupil, glaucoma, retinitis, choroiditis, optic neuritis, optic atrophy, retrobulbar neuritis, exophthalmos, lid retraction, ptosis and extra-ocular muscle palsies ${ }^{27}$.

\section{Herpes Simplex Virus (HSV)}

HSV is a DNA virus that often infects humans. HSV infection is spread by direct contact with infectious secretions from infected carriers. HSV type 1 is commonly responsible for oral and ocular infections while HSV type 2 is responsible for genital infections ${ }^{29}$. However, it is not uncommon to find HSV type 2 involved in oral and ocular infection and HSV type 1 in genital infection. Primary infection with HSV can develop at any age ${ }^{29}$. Adnexal manifestations of primary ocular HSV infection include blistering of the periorbital skin and blepharoconjunctivitis ${ }^{29}$. The peri-orbital skin blisters can spread extensively on the facial skin.

\section{Kaposi Sarcoma}

Kaposi Sarcoma (KS) is caused by Kaposi Sarcomaassociated Herpes Virus (KSHV), an organism which remains the most common cause of KS in HIV/AIDS patients $^{30,31}$. KS presents as a painless mesenchymalderived vascular tumour that often affects the skin and mucous membranes that line the mouth, nose and anus $^{32}$. Lesions originate from endothelial cells in multifocal sites in the mid-dermis and extend to the epidermis ${ }^{33}$. Until the early 1980 's, KS was a very rare disease that was found mainly in equatorial Africa and eastern Europe. In Africa it made up about 9\% of all neoplasms among African blacks7. Since the AIDS epidemic it is believed to spread more rapidly in Africa among homosexual men with AIDS 7 . KS occurs in about $25 \%$ of patients who are HIV positive ${ }^{14}$. Approximately $20 \%$ of these individuals develop asymptomatic lesions on the eyelids, conjunctiva and in rare cases the orbit 16,25 .

Skin and/or mucous membranes lesions appear as red or purple lesions which spread to other organs in the body, such as the lungs, liver or gastro-intestinal tract $^{32}$. The appearance of KS on the eyelids is similar to that of KS lesions elsewhere on the skin while conjunctival KS appears as a persistent subconjunctival haemorrhage (see Figure 2) or as a raised purplish-red mass $8,14,24$. Conjunctival lesions are most frequently seen in the inferior fornix as nodular or diffuse lesions. 


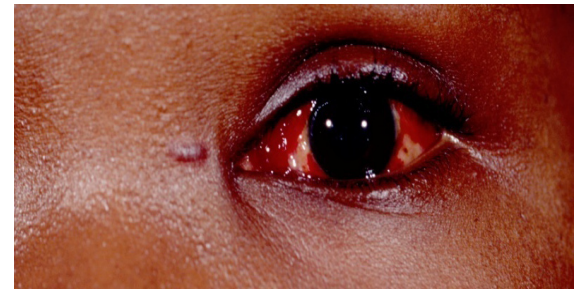

Figure 2. Kaposi sarcoma on the bulbar conjunctiva (Photo Courtesy of Dr Linda Visser)

\section{Molluscum Contagiosum (MC)}

Molluscum contagiosum is a highly contagious dermatitis that is caused by the DNA poxvirus and may affect the skin or mucous membranes ${ }^{18}$. MC occurs in children, sexually active adults and immune-compromised patients ${ }^{36}$. MC is spread by direct contact in children and through sexual activity in adults. The lesions appear as multiple, small, painless, umbilicated lesions (see Figure 3) which release poxvirus particles into the tears, resulting in an associated toxic keratoconjunctivitis. Lesions become quite large and often more numerous and more rapidly growing in HIV infected individuals ${ }^{14}$. Molluscum contagiosum is found in 5 to $18 \%$ of patients with HIV/AIDS $15,25,37$. Eyelid lesions which occur on the eyelid and conjunctiva have been found in up to $5 \%$ of HIV infected people14, 35, 38. KC lesions are selflimiting with spontaneous resolution which takes months to years ${ }^{39}$.

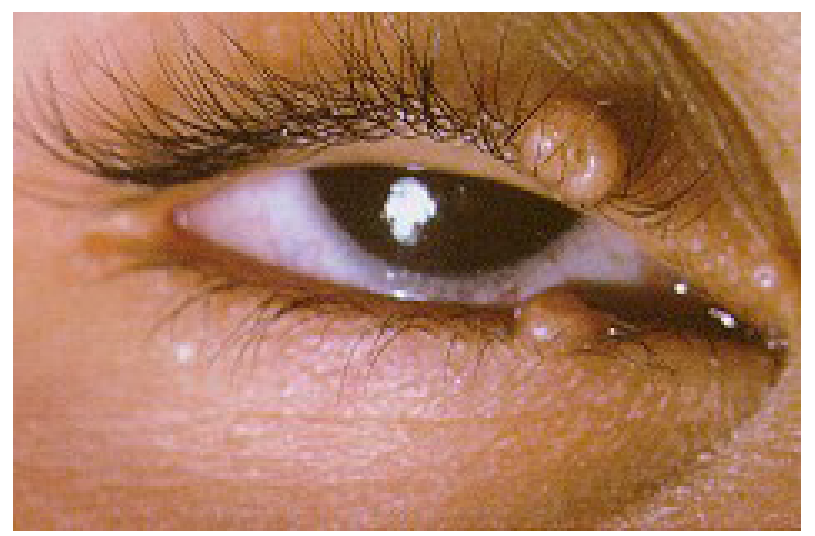

Figure 3. Molluscum contagiosum lesions in a HIV negative child (Photo Courtesy of Dr Linda Visser)

\section{Conjunctival Microvasculopathy}

There are several conjunctival microvascular changes that are commonly seen in HIV positive individuals and some have been observed in as many as $70-80 \%$ of HIV positive individuals ${ }^{11}$. The changes include capillary dilatation, irregular vessel caliber and microaneurysms $\mathrm{s}^{40}$. Conjunctival microvascular changes correlate with the presence of retinal microvasculopathy ${ }^{25}$. The microvasculopathy is believed to be due to increased plasma viscosity and immune-complex deposition, however, a specific etiology is not known ${ }^{25}$. Tufail et al ${ }^{41}$ suggested that the severity of conjunctival microvascular changes correlated with increased zeta sedimentation ratios, that is, the measure of red cell aggregation, and with fibrinogen levels. Direct infection of the conjunctival vascular endothelium has also been suggested as a possible cause of microvascular changes ${ }^{25}$.

\section{Anterior Segment Ocular Manifestations of HIV/ AIDS}

Anterior segment manifestations of HIV/AIDS have been noted in about $50 \%$ of HIV-infected individuals 15 and include corneal infection (keratitis) and anterior chamber inflammation (iridocyclitis). Common symptoms include irritation, pain, photophobia and decreased vision.

\section{Infectious Keratitis}

Infectious keratitis in HIV-infected individuals may be caused by viral, bacterial, fungal or protozoan infections ${ }^{38,42}$. It has been noted that the etiologic and epidemiologic pattern of corneal ulceration varies with patient population, geographical location and climate and has most commonly been caused by VZV and Herpes Simplex Virus (HSV) in HIV positive individuals ${ }^{42}$. When it occurs due to VZV, the keratitis is associated with HZO, with or without the presence of dermatitis. Keratitis due to VZV and HSV, has been found to recur quite frequently in HIV positive individuals and has been found to be resistant to treatment ${ }^{11}$. Keratitis due to bacterial or fungal causes has not been found to be more common in HIV positive individuals. However, when found, its severity is greater. The most common fungal organisms have been found to be candida, especially in intravenous drug users while microsporidia has emerged as a very common protozoan opportunistic organism $^{25}$.

\section{Varicella-Zoster Virus Keratitis}

Varicella Zoster Virus (VZV) has been reported to be the second most common ocular pathogen in HIV- 
infected individuals ${ }^{43}$. Following primary infection by the VZV, reactivation can occur and presents as HZO which may occur with or without dermatitis. Clinical features of HZO may be due to direct viral infection, antigen-antibody reactions, delayed cellmediated hypersensitivity reactions or neurotrophic damage ${ }^{19}$. VZV like HSV establishes a latency period after primary infection due to their morphological similarities. Reactivation of the disease occurs when the host individual's immune system is compromised. The keratitis occurs in less than 5\% of HIV positive individuals and can result in permanent vision loss when there is corneal involvement ${ }^{15,25}$. The lesions contain live virus and may resolve or progress to dendrites which present 4 to 6 days after infection. The dendrites appear as elevated plaques and consist of swollen epithelial cells. The lesions present with tapered ends compared to the terminal end bulbs seen with HSV.

\section{Herpes Simplex Keratitis (HSK)}

HSK is caused by KSV, the same DNA virus that causes the adnexal manifestations of periorbital blisters and blepharoconjunctivitis. HSK is characterised by painful, recurrent corneal ulcerations which bear a characteristic branching or dendritic pattern ${ }^{8}$. While the incidence of herpes simplex keratitis does not appear to be higher in individuals with AIDS, Rao ${ }^{44}$ observed it to have a more prolonged course while Hodge and Margolis ${ }^{45}$ found only the recurrence rate affected while the clinical course and incidence unaffected between HIV positive and negative individuals.

Other common sequelae found in primary ocular HSV infection include stromal scarring and uveitis in addition to the adnexal abnormalities. The conjunctivitis is typically follicular and is usually accompanied by pre-auricular lymphadenopathy. According to Suresh and Tullo ${ }^{29}$ the keratitis develops within a few days in $30-50 \%$ of cases after conjunctival involvement. The corneal lesions range from superficial punctate keratitis, stellate epithelial lesions, microdendrites, dendritic ulceration or geographic ulceration ${ }^{29}$. On simple observation, the infected epithelial cells appear as opaque lesions which form white plaques. However, on extensive examination, typically centrally located dendritic ulceration can be observed (see Figure 4). The exact mechanism of dendrite formation is not known, however, research indicates that it is related to the linear spread of the virus from cell to cell in a contiguous manner ${ }^{29}$.

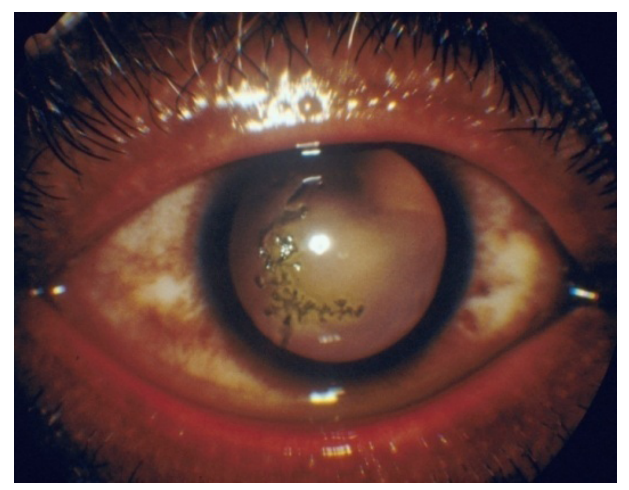

Figure 4. Herpes Simplex Dendritic ulcer (Photo Courtesy of Dr Linda Visser)

\section{Bacterial keratitis}

The most common pathogens causing bacterial keratitis include Staphylococcus aureus, Staphylococcus epidermis and Pseudomonas aeruginosa ${ }^{46}$. Bacterial keratitis represents an opportunistic infection of the avascular corneal stroma and it is initiated by a breakdown of the epithelial barrier ${ }^{47}$.

\section{Fungal keratitis}

Candida species are the most common fungal organisms causing keratitis in HIV positive individuals, especially in intravenous drug users while other fungal organisms also include Fusarium or Aspergillus species ${ }^{25}$. Immune-suppression in HIV positive individuals predisposes them to infection by these fungal organisms with resultant fungal infections presenting with greater severity ${ }^{14}$. The nonfilamentous fungi (Candida species) are very common in already compromised eyes, particularly immunecompromised eyes while filamentous fungi (For example, Fusarium or Aspergillus species) are seen in association with trauma with vegetable matter.

\section{Microsporidia}

Microsporidia are obligate intracellular protozoan parasites belonging to Phylum Microsporidia ${ }^{48}$. There are approximately 14 different species that have been identified as human pathogens which are capable of causing intestinal, sinus, pulmonary, ocular, muscular and renal disease in both immune-competent and immune-compromised individuals ${ }^{48,49}$. Five species 
have been identified in HIV positive individuals, however, the most commonly identified organism in HIV infected individuals is Enterocytozoan Bieneusi which is commonly observed in individuals with CD4+ lymphocyte counts of less than 50 cells $/ \mathrm{mm}^{3}$. Ocular manifestations though uncommon, include keratoconjunctivitis (which is most commonly seen in immune-compromised individuals) and stromal keratitis (which is most commonly seen in immunecompetent individuals).

\section{Iridocyclitis}

Uveitis presents as one of the earlier signs of several chronic infections that are frequently observed in HIV infected individuals which include tuberculosis, syphilis, histoplasmosis, coccidiodomycosis and toxoplasmosis ${ }^{8}$. Mild iridocyclitis is often associated with retinitis due to CMV or VZV while severe iridocyclitis is seen in association with ocular toxoplasmosis, tuberculosis, syphilis or rarely bacterial or fungal retinitis ${ }^{25}$. Medications prescribed for HIV positive individuals, like rifabutin or cidofovir can also cause iridocyclitis. Cells in the anterior chamber, keratic precipitates, posterior synechiae, segmental iris necrosis and hypopyon are among the clinical signs of anterior uveitis ${ }^{8,} 29$. According to Cunningham and Margolis ${ }^{11}$, uveitis in HIV positive individuals is usually due to posterior segment disease with the most common being CMV retinitis.

Part two of the review series will comprise the posterior segment, neuro-ophthalmic and iatrogenic manifestations of HIV/AIDS.

\section{References}

1. O’ Brien SJ, Goedert JJ. HIV causes AIDS: Koch's postulates fulfilled. Guest Editorial. Curr Opin Immunol 19968 613-618.

2. Singh A, Bairy I, Shivananda PG. Spectrum of opportunistic infections in AIDS cases. Ind J Med Sci 200357 16-21.

3. Centers for Disease Control (CDC). Pneumocystis Pneumonia-Los Angeles. Morb Mort Weekly Report 198130 13.

4. GeoHive website. The demographic status of the world's population. [Online] Available from: http://www.geohive. com/earth/world.aspx. 2008. Date accessed: 12/2008.

5. Kaizer Family Foundation. HIV/AIDS epidemic in South Africa. HIV/AIDS Policy Fact Sheet. [Online] Available from: http://www.kff.org/hivaids/upload/7365-065.pdf. 2008. Date accessed: 10/2008.
6. Maclean H, Hall AJ, McCombe MF, Sandland AM. AIDS and the eye: A 10 year experience. Aus New Zeal J Ophthalmol 199624 61-67.

7. Friedman AH. The retinal lesions of the acquired immune deficiency syndrome. Trans Am Ophthalmol Soc 198482 447-491.

8. Ahmed I, Ai E, Luckie A. Ophthalmic manifestations of HIV. HIV InSite Knowledge Base Chapter. [Online] Available from: http://hivinsite.ucsf.edu. 2005. Date accessed: 03/2006.

9. Pavan-Langston DP. Manual of Ocular Diagnosis and Therapy, (6th Ed). Philadelphia: Lippincott, Williams \& Wilkins, 2007.

10. Lewallen S. HIV/AIDS: What is the impact on prevention of blindness programmes? J Com Eye Health 2003 $1633-34$.

11. Cunningham ET, Margolis TP. Ocular manifestations of HIV infection. The New Eng J Med 1998339 236-244.

12. Sahu DK, Namperumalsamy P, Walimbe P, Rajalakshmi C. Ocular manifestations of HIV infection/AIDS in South Indian patients. Ind $J$ Ophthalmol 199947 79-85.

13. Biswas J, Sudharshan S. Anterior segment manifestations of human immunodeficiency virus/Acquired immune deficiency syndrome. Ind J Ophthalmol 200856 363-375.

14. Lima BR. Ophthalmic Manifestations of HIV infection. Dig J Ophthalmol [Online] Available from: http://www.djo. harvard.edu/print.php?url=/physicians/oa/674\&print $=1$. 2004. Date accessed: 04/2005.

15. Shukla DS, Rathinam SR, Cunningham ET. Contribution of HIV/AIDS Global Blindness. Int Ophthalmol Clin 2007 $4727-43$.

16. Jeng BH, Holland GN, Lowder CY, Deegan WF, Raizman MB, Meisler DM. Anterior segment and external ocular disorders associated with Human Immunodeficiency Virus disease. Surv Ophthalmol 200752 329-368.

17. Friedlaender MH, Masi RJ, Osumoto M, Smolin G, Ammann AJ. Ocular microbial flora in immunodeficient patients. Arch Ophthalmol 198098 1211-1213.

18. Chronister CL, Cohen NA, Stevens SA. How to detect, treat and contain infectious diseases. Rev Optom 1999136 $65-77$.

19. Waife B. Herpes Zoster Ophthalmicus in HIV/AIDS. $J$ Com Eye Health 200316 35-36.

20. Margolis TP, Milner MS, Shama A, Hodge W, Seiff S. Herpes Zoster Ophthalmicus in patients with human immunodeficiency virus infection. Am J Ophthalmol 1998125 285-291.

21. Sarraf D, Ernest JT. Aids and the eyes. Lancet 1996348 525-528.

22. Karbassi M, Raizman MB, Schuman JS. Herpes Zoster Ophthalmicus. Surv Ophthalmol 199236 395-410.

23. Bayu S, Alemayehu W. Clinical profile of Herpes Zoster Ophthalmicus in Ethiopians. Clin Infect Dis 199724 12561260.

24. Pavan-Langston DP. Manual of Ocular Diagnosis and Therapy, 5th Edition. Philadelphia. Lippincott, Williams \& Wilkins, 2002. 
25. Copeland R, Phillpotts BA. Ocular manifestations of HIV. EMedicine Website. [Online] Available from: www.emedicine.com/OPH/topic261.htm. 2009. Date accessed: 04/ 2005.

26. Gurwood AS, Savochka J. Herpes Zoster Ophthalmicus. Optom Today 2001 November 38-41.

27. Moon JE, Hospenthal DR. Herpes Zoster. EMedicine Website. [Online] Available from: http://www.emedicine. com/Med/topic1007.htm. 2008. Date accessed: 07/ 2008.

28. Visser L. The eye and HIV/AIDS. Cont Med Edu 200725 493-495.

29. Suresh PS, Tullo AB. Herpes Simplex Keratitis. Ind $J$ Ophthalmol 199947 155-165.

30. Gange SJ, Barrón Y, Greenblatt RM, Anastos K, Minkoff H, Young M, Kovacs A, Cohen M, Meyer WA and Muñoz A. Effectiveness of highly active antiretroviral therapy among HIV-1 infected woman. J Epidem Com Health 200256 153-159.

31. Brown EE, Fallin MD, Goedert JJ, Hutchinson A, Vitale F, Lauria C, Giuliani M, Marshall V, Mbisa G, Serraino D, Messina A, Durum S, Whitby D, Chanock SJ and the Kaposi Sarcoma Genetics Working Group. Host immunogenetics and control of human herpesvirus- 8 infection. J Inf Diseases 2006193 1054-1062.

32. National Cancer Institute. Kaposi Sarcoma: Treatment Patient Information. [Online] Available from: http://www. cancer.gov/cancertopics/pdq/treatment/kaposis/Patient. 2005. Date accessed: 06/2006.

33. Porter RS, Kaplan JL, Homeier BP and Beers MH. The Merck Manuals Online Medical Library. [Online] Available from: http://www.merck.com/mmpe/sec10/ch128/ ch128d.html 2008. Date accessed: 08/2008.

34. Suresh K. Ophthalmic manifestations of HIV infection. Ind J Prac Doc 200631 2006-08-2006-09. [Online] Available from: http://www.indmedica.com/journals.php?journ alid $=3 \&$ issueid $=84 \&$ articleid $=1145 \&$ action $=$ article Date accessed: 07/2008.

35. Bhatia RS. Ophthalmic manifestations of AIDS. $J$ Ind Acad Clin Med 20023 85-88.

36. Watanabe T, Nakamura K, Wakugawa M, Kato A, Nagai Y, Shioda T, Iwamoto A and Tamaki K. Antibodies to Molluscum Contagiosum Virus in the General Population and Susceptible Patients. Arch Derm 2000136 1518-1522.

37. Gottlieb SL and Myskowski PL. Molluscum contagiosum. Int J Derm 199433 453-461.

38. Moraes HV. Ocular manifestations of HIV/AIDS. Curr Opin Ophthalmol 200213 397-403.

39. Maurer TA and Berger TG. Dermatological manifestations of HIV. HIV InSite Knowledge Base Chapter. [Online] Available from: http://hivinsite.ucsf.edu/InSite?page=kb-

40. 04-01-01. 1998. Date accessed: 06/2006.

Sowka JW, Gurwood AS and Kabat AG. Handbook of ocular disease management. [Online] Available from: http:// www.revoptom.com/cmsdocuments/2009/9/ro0409_hand-

41. book.pdf. 2009. Date accessed: 06/2008.

Tufail A, Meiselman HJ, Engstrom RE, Hardy JRWD, Holland $\mathrm{G}$ and Holland N. Hemorheologic abnormalities and ophthalmic disease in patients with human immunodeficiency virus infection. Biorheology 1995 32 336-336.

42. Sirikul T, Prabriputaloong T, Smathivat A, Chuck RS and Vongthongsri A. Predisposing factors and etiologic diagnosis of ulcerative keratitis. Clin Sci 200827 283-287.

43. Franco-Paredes C, Bellehemeur T, Merchant A, Sanghi P, Diaz Granados C and Rimland D. Aseptic meningitis and optic neuritis preceding varicella-zoster progressive outer retinal necrosis in a patient with AIDS. AIDS $2002 \mathbf{1 6}$ 1045-1049.

44. Rao NA. Acquired immunodeficiency syndrome and its ocular complications. Ind J Ophthalmol 199442 51-63.

45. Hodge WG and Margolis TP. Herpes simplex virus keratitis among patients who are positive or negative for human immunodeficiency virus: An epidemiological study. Ophthalmology 19974 120-124.

46. Cunningham ET and Belfort E. HIV/AIDS and the Eye: Global Perspective. In Moraes, HV. Ocular manifestations of HIV/AIDS. Curr Opin Ophthalmol 200213 397-403.

47. Limberg MB. A review of bacterial keratitis and bacterial conjunctivitis. Am J Ophthalmol 1991112 2S-9S.

48. Omalu ICJ, Yako AB, Duhlinska DD, Anyanwu GI, Pam VA and Inyama PU. First detection of intestinal microsporidia in Northern Nigeria. Online Journal of Health and Allied Sciences, 4. [Online] Available from: http://www.ojhas. org/issue 19/2006-3-2.htm. 2006. Date accessed: 08/2008.

49. Joseph J, Vemuganti GK and Sharma S. Microsporidia: Emerging ocular pathogens. Ind J Med Micro 200523 8091 